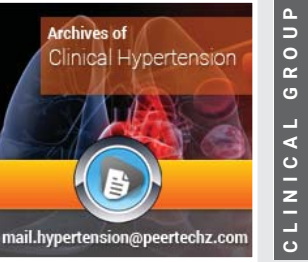

\title{
Current approach to isolated diastolic hypertension
}

\section{Hüsnü Değirmenci*, Eftal Murat Bakirci, Murat Çakir and Halil İbrahim Tanrıseven}

Department of Cardiology, Faculty of Medicine, Erzincan Binali Yildirim University, Turkey
Received: 19 December, 2020

Accepted: 29 December, 2020

Published: 30 December, 2020

*Corresponding author: Hüsnü Değirmenci, Department of Cardiology, Faculty of Medicine, Erzincan Binali Yildirim University, Turkey, Tel: 05304645530 ;

E-mail: husnudr1982@gmail.com

Keywords: Isolated diastolic hypertension; Definition; Mechanism; Risk factors; Treatment

https://www.peertechz.com

\section{Check for updates}

\begin{abstract}
In various guidelines, isolated diastolic hypertension is defined as diastolic blood pressure $>80$ or $>90 \mathrm{mmHg}$ in individuals with normal systolic blood pressure. While isolated diastolic hypertension was associated with adverse cardiovascular events in observational studies, this relationship is not clear in epidemiological studies. Increased arterial stiffness, increased central hemodynamics, vasoconstriction, increased adrenergic activity, increased renin angiotensin aldesteron activity play a role in the pathophysiology. Isolated diastolic hypertension is associated with male gender, young age, increased body mass index, increased glucose level, increased alcohol consumption and high triglyceride levels. Although treatment is not recommended in young people in isolated diastolic hypertension, treatment should be individualized according to the underlying cardiovascular disease in the elderly.
\end{abstract}

\section{Introduction}

Hypertension (HT) is one of the most common chronic diseases that increase cardiovascular morbidity and mortality [1]. HT is seen in $32 \%$ of women, $19 \%$ of men, $36 \%$ of blacks and $21 \%$ of whites [2]. Although systolic HT is frequently mentioned in various articles, the number of articles on isolated diastolic HT (IDHT) is not sufficient. IDHT is seen in $<20 \%$ of hypertensive patients [3]. The prevalence of IDHT has increased from $1.3 \%$ to $6.5 \%$ [4]. This rise has led attention to IDHT. Therefore, in this article, we present the current approach to isolated diastolic hypertension.

\section{Diastolic blood pressure and cardiovascular risk}

Although Systolic Blood Pressure (SBP) is more associated with adverse cardiovascular events, diastolic hypertension has also been found to affect adverse cardiovascular events [4]. Observational studies have found a relationship between the degree of Diastolic Blood Pressure (DBP) and cardiovascular events [5]. In a meta-analysis of 61 prospective studies, the risk of cardiovascular disease increased in a log-linear fashion with DBP $<75 \mathrm{mmHg}$ or $>115 \mathrm{mmHg}$ [6]. In observational study with 1 million adult patients aged 30 years and older found an association between elevated DBP and increased risk of cardiovascular disease, angina, myocardial infarction, heart failure, stroke, peripheral artery disease, and abdominal aortic aneurysm [7]. There is a relationship between increased risk of cardiovascular disease and high diastolic blood pressure in a wide age range from 30 years to over 80 years [6]. A $10 \mathrm{mmHg}$ increase in DBP has been associated with a doubling risk of death from stroke, heart disease, and other vascular diseases [7]. In epidemiological studies, unlike SBP, no relationship was found between DBP and cardiovascular risk [7]. Pulse pressure and mean blood pressure, independent of DBP, have been associated with cardiovascular risk in some studies $[8,9]$. In the NHANES (National Health and Nutrition Examination Survey) study [10], which included 23272 participants, more than $50 \%$ of those who died from stroke and coronary artery disease were hypertensive patients. Even at the high thresholds recommended in The Joint National Committee-7 blood pressure management guidelines, a rare association was found between IDHT and adverse cardiovascular events in elderly patients [5].

\section{Definition}

Ideal blood pressure value is $<120 / 80$. According to the 2017 American guideline, the SBP value is $<130 \mathrm{mmHg}$; A DBP value of $>80 \mathrm{mmHg}$ is defined as IDHT [5]. According to the 2018 European guideline, SBP is $<140 \mathrm{mmHg}$; DBP $>90 \mathrm{mmHg}$ is defined as IDHT [11]. 


\section{Risk factors}

Family history of hypertension, alcohol consumption, young age, male gender, increased blood glucose, increased body mass index, high triglyceride levels and previous cardiovascular events were found to be associated with IDHT [12].

\section{Mechanisms}

While diastolic hypertension is common in people under 50 years of age, systolic hypertension is more common in people over 50 years of age due to increased atherosclerosis and arterial stiffness [13-15]. Increased arterial stiffness, increased central hemodynamics, vasoconstriction, increased adrenergic activity, excessive volume load and increased renin angiotensin aldesterone system activity are associated with IDHT $[16,17]$.

\section{Treatment}

The prevalence of IDHT is more common in younger than 50 years of age. IDHT is not generally seen in the elderly. Reducing DBP is associated with adverse cardiovascular events, especially in young people with normal SBP [18]. In the SPRINT study [13], a reduction in DBP $<68 \mathrm{mmHg}$ was associated with adverse cardiovascular outcomes due to the J curve. Although rare in elderly patients, a conservative approach is generally recommended in IDHT. Because, in normal SBP, lowering DBP may impair cerebral blood flow autoregulation. Therefore, cerebral ischemia and stroke may develop. Some authors did not recommend treatment in young people as IDHT at normal systolic blood pressure levels is not associated with adverse cardiovascular events. However, lowering DBP in elderly individuals with coronary artery disease leads to an increase in morbidity and mortality as it impairs coronary blood flow autoregulation. Myocardial perfusion is maintained especially during diastole and when DBP is $70 \mathrm{mmHg}$ and above [19]. Based on our clinical experience, we recommend individualizing the treatment in IDHT so that the DBP target is between 70 and $80 \mathrm{mmHg}$. Therefore, we do not recommend treatment for IDHT in young people, but we think that the treatment should be individualized according to the underlying cardiovascular disease in elderly patients. In a study on IDHT, it was determined that calcium channel blockers are frequently used. Calcium channel blockers were followed by angiotensin converting enzyme inhibitors, angiotensin receptor blockers and diuretics [20].

\section{Conclusion}

Since the risk of cardiovascular events is low in young patients with IDHT, no treatment is required. However, elderly patients should be individualized in such a way that the underlying cardiovascular disease and target diastolic blood pressure does not fall below $70 \mathrm{mmHg}$.

\section{References}

1. Hermida RC, Ayala DE, Fernández JR, Mojón A, Smolensky MH (2018) Hypertension: New perspective on its definition and clinical management by bedtime therapy substantially reduces cardiovascular disease risk. Eur $\mathrm{J}$ Clin Invest 48: e12909. Link: https://bit.ly/37VU1Xk
2. Willey JZ, Moon YP, Kahn E, Rodriguez CJ, Rundek T, et al. (2014) Population Attributable Risks of Hypertension and Diabetes for Cardiovascular Disease and Stroke in the Northern Manhattan Study. J Am Heart Assoc 3: e001106. Link: https://bit.ly/3mY5vOh

3. Qi SF, Zhang B, Wang HJ, Yan J, Mi YJ, et al. (2016) Prevalence of hypertension subtypes in 2011 and the trends from 1991 to 2011 among Chinese adults. J Epidemiol Community Health 70: 444-451. Link: https://bit.ly/38FX8li

4. Flint AC, Conell C, Ren X, Banki NM, Chan SL, et al. (2019) Effect of Systolic and Diastolic Blood Pressure on Cardiovascular Outcomes. N Engl J Med 381: 243-251. Link: https://pubmed.ncbi.nlm.nih.gov/31314968/

5. Reboussin DM, Allen NB, Griswold ME, Guallar E, Hong $Y$, et al. (2018) Systematic review for the 2017 ACC/AHA/AAPA/ABC/ ACPM/AGS/ APhA/ASH/ASPC/NMA/PCNA guideline for the prevention, detection, evaluation, and management of high blood pressure in adults: a report of the American College of Cardiology/American Heart Association Task Force on Clinical Practice Guidelines. J Am Coll Cardiol 71: 2176-2198. Link: https://bit.ly/3o0lfBI

6. Lewington S, Clarke R, Qizilbash N, Peto R, Collins R (2002) Prospective Studies Collaboration. Age-specific relevance of usual blood pressure to vascular mortality: a meta-analysis of individual data for one million adults in 61 prospective studies. Lancet 360: 1903-1913. Link: https://bit.ly/38PwiY9

7. Rapsomaniki E, Timmis A, George J, Pujades-Rodriguez $M$, Shah AD, et al (2014) Blood pressure and incidence of twelve cardiovascular diseases: lifetime risks, healthy life-years lost, and age-specific associations in 1.25 million people. Lancet 383: 1899-1911. Link: https://bit.ly/3aTROZe

8. Zhao L, Song Y, Dong P, Li Z, Yang X, et al. (2014) Brachial pulse pressure and cardiovascular or all-cause mortality in the general population: a metaanalysis of prospective observational studies. J Clin Hypertens (Greenwich) 16: 678-685. Link: https://bit.ly/34VkVwn

9. Kodama S, Horikawa C, Fujihara K, Yoshizawa S, Yachi Y, et al. (2014) Metaanalysis of the quantitative relation between pulse pressure and mean arterial pressure and cardiovascular risk in patients with diabetes mellitus. Am J Cardiol 113: 1058-1065. Link: https://bit.ly/3aSch5H

10. Ford ES (2011) Trends in mortality from all causes and cardiovascular disease among hypertensive and nonhypertensive adults in the United States. Circulation 123: 1737-1744. Link: https://bit.ly/35buLuv

11. Williams B, Mancia G, Spiering W, Agabiti Rosei E, Azizi M, et al. (2018) 2018 ESC/ESH Guidelines for the management of arterial hypertension. Eur Heart J 39: 3021-3104. Link: https://bit.ly/3o3oWqm

12. Mahajan S, Zhang D, He S, Lu Y, Gupta A, et al. (2019) Prevalence, Awareness, and Treatment of Isolated Diastolic Hypertension: Insights From the China PEACE Million Persons Project. J Am Heart Assoc 8: e012954. Link: https://bit.ly/2KLhxxo

13. Khan NA, Rabkin SW, Zhao Y, McAlister FA, Park JE, et al. (2018) Effect of lowering diastolic pressure in patients with and without cardiovascular disease. Analysis of the SPRINT (Systolic Blood Pressure Intervention Trial). Hypertension 71: 840-857. Link: https://bit.ly/3aW26wW

14. Franklin SS, Pio JR, Wong ND, Larson MG, Leip EP, et al. (2005) Predictors of new-onset diastolic and systolic hypertension. The Framingham Heart Study. Circulation 111: 1121-1127. Link: https://bit.ly/2KMawfJ

15. Lowes CMM, Vander Horn S, Rodgers A (2001) Global burden of blood pressure related disease. Lancet 371: 1413-1518.

16. Laragh JH (1988) Pathophysiology of diastolic hypertension. Health Psychol 7:15-31. Link: https://bit.ly/34VIITt

17. Odaira M, Tomiyama H, Yoshida M, Shiina K, et al. (2013) Isolated diastolic hypertension: possible underlying mechanisms of its development. Eur Heart J 34: P2370. Link: https://bit.ly/2WWVO8i 
18. Chrysant SG (2020) The clinical significance of isolated diastolic hypertension Postgraduate Medicine 132: 624-628. Link: https://bit.ly/37XOdMK

19. Chrysant SG, Chrysant GS (2010) Effectiveness of lowering blood pressure to prevent stroke versus to prevent coronary events. Am J Cardiol 106: 825-829. Link: https://bit.ly/3o3oU1x
20. Fang J, Madhavan S, Cohen H, Alderman MH (1995) Isolated Diastolic Hypertension. Hypertension 26: 377-382. Link: https://bit.ly/2WUOYA2
Discover a bigger Impact and Visibility of your article publication with

Peertechz Publications

\section{Highlights}

* Signatory publisher of ORCID

* Signatory Publisher of DORA (San Francisco Declaration on Research Assessment)

* Articles archived in worlds' renowned service providers such as Portico, CNKI, AGRIS, TDNet, Base (Bielefeld University Library), CrossRef, Scilit, J-Gate etc.

* Journals indexed in ICMJE, SHERPA/ROMEO, Google Scholar etc.

* OAI-PMH (Open Archives Initiative Protocol for Metadata Harvesting)

- Dedicated Editorial Board for every journal

* Accurate and rapid peer-review process

* Increased citations of published articles through promotions

* Reduced timeline for article publication

Submit your articles and experience a new surge in publication services (https://www.peertechz.com/submission).

Peertechz journals wishes everlasting success in your every endeavours.

Copyright: ( 2020 Değirmenci H, et al. This is an open-access article distributed under the terms of the Creative Commons Attribution License, which permits unrestricted use, distribution, and reproduction in any medium, provided the original author and source are credited. 